\title{
Archives as a Defense System of Indonesian Maritime Sovereignty
}

\author{
Lita Tyesta ALW \\ Diponegoro University, Indonesia \\ litatyestalita@yahoo.com
}

\author{
Amalia Diamantina \\ Diponegoro University, Indonesia \\ amaliadiamantina.undip@gmail.com
}

\begin{abstract}
Archives are unique and irreplaceable heritage passing through generations. Archives are managed from creation to preserve their value and meaning. They are authoritative sources of information underpinning accountable and transparent administrative actions. Archive system is also essential to preserve the legitimacy of sovereign state especially when it comes to border protection. Given the fact that Indonesia is a strategic archipelagic maritime state in which its borders are defined by the outermost coastal lines of the outermost small islands (PPKT), the protection and security systems are not only defined by military power but also through a legitimate documentation archives of these border islands. The archives are managed by archive system as the part of national assets. It is a national asset because these archives are the authentic evidences about the state's sovereignty upon the borders. Therefore, archives are also essential to secure the legitimacy of Indonesian maritime borders. This study discussed the implementation of Indonesian Archive System as mandated in the Law No.43/2009 on Archive and its real challenges upon globalization, good governance and public services. The methods of the research were normative approach and conceptual approach. This study concluded that the implementation of archive system as a maritime defense must integrated into a comprehensive system of national archive which also documented border islands in relation with state institutions, regional governments, education institutions, companies, political organization, civil society organization and population history.
\end{abstract}

Keywords: Archives System, Secure the Legitimating, Indonesian Maritim State.

\section{INTRODUCTION}

On December $17^{\text {th }}, 2002$, the International Court of Justice (ICJ) in The Hague, Netherlands granted Malaysian claim upon the dispute of Sipadan and Ligitan Islands in the coast of Eastern Borneo. Sipadan and Ligitan were once included within Indonesian sovereignty since the state's independence. However, the fact that Malaysia could won their claim upon the islands successfully in ICJ was because of Malaysian comprehensive documentations and archives about Malaysian history on the islands. Despite decades of the islands' tenures under Indonesian sovereignty, the ICJ was more convinced by Malaysian evidences upon the islands rather than Indonesian. Meanwhile, Indonesian representatives in the ICJ - as a defendant- could not fulfill their burden of evidence about the islands' tenure. Apparently, Indonesian representatives were lack of well-documented evidences such as photos, maps, witness narratives, documented testimonies, and so forth.
One of the weakness points of Indonesian claim was their incomprehensive archive system which had not improved and updated their historical archives.

Regionally, on August $20^{\text {th }}, 2015$, the provincial government of Central Java lost one of its iconic cultural assets, PRPP (Pusat Rekreasi dan Promosi Pembangunan, Development Promotion and Recreation Center trans.), through the Semarang Regional Court's decision. The decision ruled that PRPP is now released for a private ownership. The release of one of the precious assets of Central Java government by the court was caused by the inability of the government to provide their land ownership license, which was missing in their archive system. This shows that archive systems in Indonesian government and bureaucracy are not wellmanaged. And this is dangerous because archive is one of the most important assets of the government. It is the only legal evidence that could be brought upon the court to validate any claims. If this system is broken down, it is very likely that the state would lose its sovereignty upon its own land.

Two examples of the case above make us aware of the importance of file storage as an authentic evidence of ownership asset both State and local government in the form of archives because archives have an important role in organizational heritage, both to government and private organizations. Benefits of archives for an organization include information that is useful in decision making and serving evidence if there is a problem. In the broader context, archive is a responsibility material of governance, development and society. This is what encourages the normative study of how the archive arrangement saves the State assets as a Maritime Country, especially to the assets of the outermost islands that cover the territory of Indonesia.

\section{METHOD}

This study used normative approach with prescriptive optics to find out the rule of law that determines what are the legal rights and obligations of the subject and the object of law in certain social situations. The first approach was the statutory approach used to review the laws and regulations governing the organization of archives so that it can be explained from the perspective of the science of legislation. The materials to be reviewed were various laws and regulations related to the arrangement of filing operations from the law to the implementing regulations. The second was conceptual approach used to deepen the concept of organizing the 
development of archives in the system of the Republic of Indonesia as a Maritime Country. The aim is to find an understanding of the legislators and the scientists' opinions about the archives and concepts of maritime that lead to the values of Pancasila as the source of all sources of law.

The main objects of study in this study are legal sources, which are: Law No. 43/2009 on Archive; Law No.12/2011 on Legislation Formulation; Law No. $17 / 1985$ on Ratification of the United Nations Convention on the Law of the Sea (UNCLOS); Law No. 6/1996 on Indonesian Waters; Government Regulation No. 38/2002 on the List of Geographical Coordinate Points of the Baseline of Indonesian Archipelago; Government Regulation No. 62/2010 on the Utilization of the Outermost Small Islands; Presidential Order No. $78 / 2005$ on the Management of Indonesia's Outermost Small Islands.

Regarding the legal sources that are used, the analysis will be outlined through prescriptive-descriptive method. This method is used to give argumentations based on the result of the research. These arguments are given as prescription and assessment on how the regulations of archive can integrate other legislations regarding national asset management.

\section{RESULT}

The definition of national asset, as stipulated in the Law No. 17/2003 on State Finance, encompasses all of the rights and duties of the state which can be monetized, and also every goods and services that are privately owned by the state. According to the Minister of Finance Order No. 225/1971, No. 350/1994, and No. 370/1994, national assets are every commodities, movable or immovable, tangible or intangible, bought by using the state budget and other legal means, owned or managed by non-ministerial government institutions and government-mandated bodies, not including separated assets and regional governments' assets. It is clear that national assets can be utilized under the state's consideration for the thrive of people prosperity as mandated in Article 33 of the 1945 Constitution, including the outermost islands which are bordered with other countries and must be maintained as a manifestation of Indonesia sovereignty.

Regarding the utilization of Indonesia's outermost islands, on March $2^{\text {nd }}, 2017$, the Indonesian government has enacted the Presidential Order No. 6/2017 on the Establishment of Outermost Islands which was originally amended from Presidential Order No. 78/2005 on the Management of Outermost Small Islands. The previous presidential order was only established ninety two (92) coordinate points which constituted from the outermost small islands. In accordance with the Government Regulation No. 37/2009 on List of Geographical Coordinate Points of Indonesia's Archipelago baseline, there has been an increase of amount of outermost small islands to 111 islands. Therefore, the newest presidential order was made to be in accordance with the updated data of the Government Regulation No. 37/2009. This is important as these outermost islands constitute borders and sovereignty, thus, these islands are one of the most vital assets of the government. This is the reason why the government is keeping their inventory lists updated, because this is intended not only to minimalize the interferences against national security, but also to defend the state sovereignty upon its land. Given the fact, there is an issue of private takeovers of these islands either from foreign citizens or foreign companies in order to utilize these islands for despicable crimes, such as drug smuggling, human trafficking, illegal dumping, and illegal fishing.

Historical assets are priceless and can be utilized to advance the nation. It is also embodied in the nine points of the Working Cabinet program led by President Joko Widodo. Records/asset documents are the historic assets that contain information of assets owned by an agency/organization, region, and even country. As an asset, the archive/document is potential to be utilized in the future, to support the role and function of government as a provider of public services to the community, and the creation of good governance. The number of cases related to the defeat of a country/region to maintain its property assets, especially the assets of the nation's wealth. Including the intellectual property of the nation, they certainly have implications for the state's efforts in building a national strategic industry in order to compete with other countries. Therefore, the management of state assets/assets belonging to one of the vital archives contained in an agency should be of particular concern as an evidence of creating accountability, legal evidence and organizational memory which are vital archives for an organization, as mandated in Law No. 43/2009 on Archive. The seriousness of managing information about the nation's intellectual property assets should be interpreted as a state effort to strengthen information security as part of national security.

According to the Glossary of Archival and Records Terminology, archive is a noun, which is defined as:

"Materials created or received by a person, family, or organization, public or private, in the conduct of their affairs and preserved because of the enduring value contained in the information they contain or as evidence of the functions and responsibilities of their creator, especially those materials maintained using the principles of provenance, original order, and collective control; permanent records."

The scope of the archive is so broad, not just a stack of files that are stored to open at any time when needed. Because of the importance of the archives and to ensure the availability of authentic and reliable archives as evidence, the Government of Indonesia established Law No. 43 Year 2009 on Archives. Article 43 Paragraph (1) of Law No. 43/2009 on Archive which expressly states that the State specifically provides protection and rescue of archives related to population, territories, islands, borders, international agreements, contracts of work, and strategic governance issues, then the law is positively the state has committed to the protection and rescue of the 
essential state archives that are born on the implementation of a community activity, nation and state. With reference to the aforementioned article, it becomes the obligation of the Government to manage the archipelago of the border region consisting of outermost small islands (PPKT) so that Indonesia will no longer lose small islands bordering with other countries.

The management of the archives of border areas shall be carried out by means of filing, reporting and submitting authentic manuscripts to ANRI (National Archives of Republik Indonesia) as mandated in Article 43 paragraph (2) and paragraph (3) of Law No. 43/2009 on Archive. Maintaining the territorial border of the state as part of the territory of the sovereignty of the Unitary State of the Republic of Indonesia is not only the de facto mastery of the territory, but also the de jure control through the ownership of its archives as authentic proof of ownership of the state border territory. With the possession of archives of territoriality, border areas consisting of outermost small islands are complete and accurate, then Indonesia can explain to the other countries that will claim the borders because Indonesia has a complete history of the region from birth and history of development of the borders. The rescue of the archives of state borders is essentially an integral part of national security development. With the archives of the border areas of the State of Indonesia, this has a strategic value to support the successful development of national security and defence because it has an impact on conditions of defence and security both in regional and national levels and have interrelated relationships with activities carried out in the territory of other countries.

Implementation of archival affairs has a significant influence to create security, defence and good governance of both central and regional governance. The implementation of archival affairs is not only related to archive storage, but also includes many things, ranging from archive collection, archive management / preservation, archive storage, to archive utilization. With the implementation of integrated archive affairs at all institutions pertaining to the ownership and management of State assets, this is very beneficial to the state in relation to the rescue of the borders of Indonesia which mostly consist of outermost small islands.

\section{CONCLUSION}

Archive is basically the interest of all parties, i.e. individuals, communities, governments, and the business world. How important and urgent the issue of archives, especially for the protection and management of State assets, are able to overcome the disintegration of the nation while maintaining the integrity of the Unitary Republic of Indonesia through the management and protection of archives of border areas consisting of outermost small islands. Therefore, regulation of archives should be integrated in various legislations related to the main assets. In accordance with the conclusion, the drafting of legislation regarding national asset management in the future must include a procedure of archiving in accordance with Law No. 43/2009 on Archive.

\section{REFERENCES}

[1] Arif Havas Oegroseno. 2004. Delimitasi Batas Maritim dalam Kebijakan Border Diplomacy Indonesia. Makalah Lokakarya Hukum Laut Internasional. Yogyakarta 13-15 Desember 2004.

[2] Azmi, Kajian Arsip Wilayah Perbatasan Negara Dalam Rangka Perlindungan dan Penyelamatan Arsip Terjaga di Lingkungan Lembaga Negara dan Pemerintah Daerah, Dalam Jurnal Vol.6/ANRI/12/2011.

[3] ICA, Archives, Harmony And Friendship: Sustaining The Spirit Of Seoul, ICA Congress 2016, 5-10 September 2016, Seoul Korea. 2016.

[4] Lili Rasidi, Filsafat Hukum, Apakah Hukum Itu?, PT. Remaja Rosdakarya Bandung, 1993

[5] Margaret Crocket, The No-Nonsense Guide To Archives and Recordkeeping, Facet Publishing, London, 2016.

[6] Odji Salman \& Anton F Susanto, Teori Hukum, Mengingat, Mengumpulkan dan Membuka Kembali, Bandung: Refika Aditama, 2015

[7] Sudikno Mertokusumo, Mengenal Hukum Suatu Pengantar, Liberty Yogyakarta,1986

[8] Satjipto Rahardjo, Ilmu Hukum, PT. Citra Aditya Bakti, Bandung, 1991

[9] The Society of American Archivists, Glossary of Archival and Records Terminology, Chicago, IL, 2005.

[10] UNESCO, Deklarasi Universal Tentang Kearsipan, diadopsi oleh Majelis Umum Dewan Kearsipan Internasional, di Oslo September 2010 dan kemudian disyahkan dalam Sidang Ke-36 Sidang Umum UNESCO, Paris November 2011.

[11] Undang-Undang Dasar Negara Republik Indonesia Tahun 1945.

[12] Undang-Undang Nomor 17 Tahun 1985 tentang Pengesahan United Nations Convention on the Law of the Seal Konvensi Perserikatan BangsaBangsa tentang Hukum Laut.

[13] Undang-Undang Nomor 6 Tahun 1996 tentang Perairan Indonesia

[14] Undang-Undang Nomor 43 Tahun 2009 tentang Kearsipan.

[15] Undang-Undang Nomor 12 Tahun 2011 tentang Pembentukan Peraturan Perundangundangan.

[16] Undang-Undang Nomor 23 Tahun 2014 tentang Pemerintahan Daerah sebagaimana telah diubah beberapa kali terakhir dengan Undang-Undang Nomor 9 Tahun 2015 tentang Perubahan Kedua Atas UndangUndang Nomor 23 Tahun 2014 tentang Pemerintahan Daerah.

[17] Peraturan Pemeritah Nomor 37 Tahun 2008 tentang Daftar Koordinat Geografis Titik 
Titik Garis Pangkal Indonesia.

[18] Keputusan Presiden Nomer 6 Tahun 2017 tentang Penetapan Pulau-Pulau Kecil Terluar

[19] Peraturan Pemerintah Nomor 62 Tahun 2010 tentang Pemanfaatan Pulau-Pulau Kecil Terluar

[20] Peraturan Pemerintah Nomor 28 Tahun 2012 tentang Pelaksanaan Undang-Undang Nomor 43 Tahun 2009 tentang Kearsipan.
[21] Asfarsyafar.blogprot.co.id/2013, Makalah Wawasan Sosial Budaya Maritim : Pembangunan Benua Maritim Indonesia, Kamis, 10 Oktober 2013.

[22] jatengprov.go.id/Berita daerah

[23] The Society of American Archivists, Glossary of Archival and Records Terminology, Chicago, IL, 2005 